\title{
PARTICIPATION RATES OF FRESHWATER RECREATIONAL FISHERIES IN THE COUNTIES OF CROATIA
}

\author{
Tomislav Treer
}

Department of Fisheries, Apiculture, Wildlife Management and Special Zoology, Faculty of Agriculture, University of Zagreb, Svetošimunska 25, 10000 Zagreb

*Corresponding Author, Email: treer@agr.hr

\section{ARTICLE INFO}

Received: 5 July 2019

Accepted: 11 August 2019

\begin{abstract}
The aim of this research was to define the participation rates of freshwater anglers in Croatia, their changes over the years and their differences across the counties of Croatia. In spite of a continuous population decline ever since Croatia joined the EU, the number of anglers has slightly increased to around $1 \%$. The counties can be divided into three groups - counties on the Adriatic coast where marine fisheries are dominant, a very urbanized City of Zagreb and the remaining inland counties. In freshwater recreational fisheries in Croatia, the tradition and availability of fishing grounds dominate the participation rate of anglers. However, there are indications of the influence of GDP values so the counties with GDP over 6,500 euros per capita expressed positive relationship to the percentage of anglers $(p<0.05)$. On the other hand, densely populated county of the City of Zagreb confirms that urbanization and much higher GDP result in a much lower percentage of recreational fishermen.
\end{abstract}

\section{Keywords:}

Anglers

Demographics

GDP

Urbanization
Treer, T. (2019): Participation rates of freshwater recreational fisheries in the counties of Croatia. Croatian Journal of Fisheries, 77, 126-131. DOI: 10.2478/cjf-2019-0014.

\section{INTRODUCTION}

The awareness of social and health benefit of recreational fisheries, besides ecological (managing of water bodies) and economic (tourism, licences, production of angling equipment) value, has been recognized early (Driver \& Knopf, 1976) and has been rising in the new millennium (e.g. Aprahamian et al., 2010; Griffiths et al., 2017). The same has been recognized in Croatia, too. In an extensive analysis of recreational fisheries (Matulić et al., 2010), anglers pointed out relaxation and recreation (93\%), and socializing with friends (91\%) as important and very important reasons for fishing, while fishing for food was only $37 \%$. However, in recent decades declining of recreational fishing has been detected, particularly in the post-industrialized countries (Gray et al., 2003; Arlinghaus et al., 2008; Sutton, 2009; Aprahamian et al., 2010; Cowx, 2015). Some researchers observed the loss of interest in recreational fishing among younger generations (Burkett and Winkler, 2019), which in some regions of Canada resulted in an increase of the mean age of recreational fishermen by more than 12 years from the mid-1990s to 2010 (Dempson et al., 2012). Therefore, important international conferences were focused on this, which 
is visible from their titles, e.g. "Change, transformation and adaptation in recreational fishing" (da Silva et al., 2014) and "Recreational fishing in an era of change" (Aas, 2015). Arlinghaus et al. (2015) made a thorough analysis of the causes for such changes. They found out an exponential decline in fishing interest with increasing urbanization, and that interest in recreational fishing first rises with economic development and average prosperity of a country, but then declines after reaching its peak. So the aim of this research was to detect participation of freshwater anglers in Croatia, changes in participation over the years and differences across the counties of Croatia.

\section{MATERIAL AND METHODS}

The official data was obtained by the responsible Fishery Division of the Croatian Ministry of Agriculture (HŠRS, $2013,2014,2015,2016,2017)$. Data from the annual angling reports is based on data from individual angling logbooks collected from all freshwater fishing clubs in Croatia. Only angling is allowed to recreational fishermen, and besides maximum daily catch they are also limited by the number of rods and hooks which they can use, as well as by the seasons and locations closed for fishing. Midyear total population estimate of the Republic of Croatia by counties for the period 2013 - 2017 was obtained by the Croatian Bureau of Statistics (Državni zavod za statistiku, 2018) and GDP (gross domestic product) per capita by counties by the Croatian Chamber of Commerce (Hrvatska gospodarska komora, 2018). The relationship between GDP, population density of each county and the percentage of recreational fishermen was calculated by using IBM SPSS Statistics 19.

\section{RESULTS AND DISCUSSION}

The number of freshwater recreational fishermen in Croatia is around 40,000 or just below $1 \%$ of the total population, exceeding these numbers slightly in 2016 (Fig. 1). This small participation is comparable to $0.9 \%$ of Brazil, which belongs to the same GDP range group according to the International Monetary Fund and World Bank (World Bank, 2019). The other similarity is that north-eastern region of Brazil differs from other regions, as fishing occurs mostly in marine waters (Freire et al., 2016). The same is in the coastal counties of Croatia where the participation of freshwater anglers varies between 0.09 and $0.17 \%$ but with two exceptions. Lika-Senj County has a long Adriatic coast and a large inland area with the River Lika, a wellknown fishing ground.

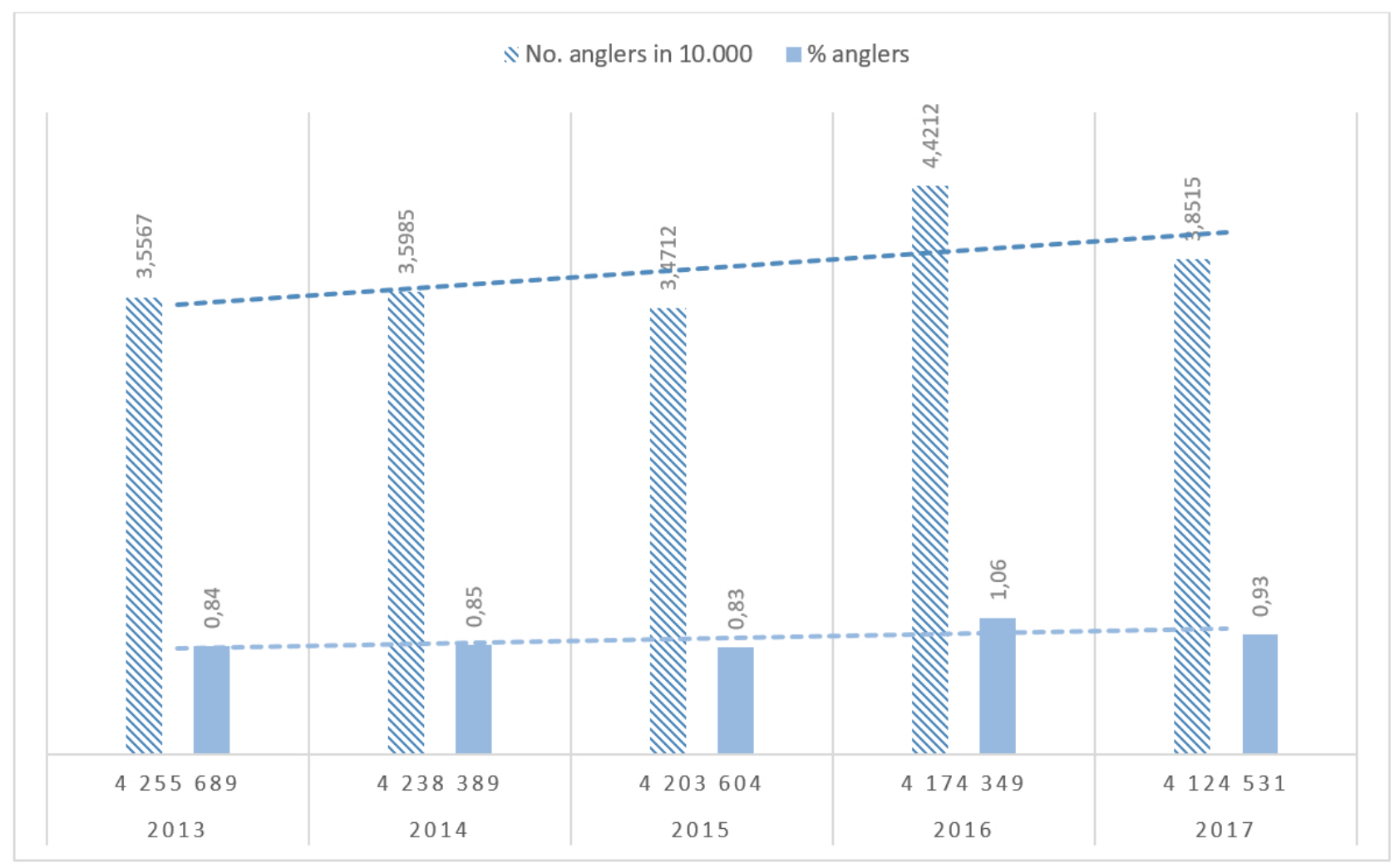

Fig 1. Number (dark columns) and percentage (\%, light columns) of freshwater anglers in Croatia from 2013 to 2017. The population of Croatia is estimated by the Croatian Bureau of Statistics (2018) 
Therefore, there are $0.92 \%$ anglers. Zadar County is a maritime county with a lot of islands. However, there is a freshwater Vransko Lake of $\mathbf{3 0 0 0}$ ha, situated just one kilometer from the sea and populated by freshwater fish from the north of Croatia ever since late 1940s. It is an internationally well-known fishing ground so there are many anglers from the rest of Croatia and other countries, making a comparatively high participation rate of 3.93\% (Fig. 2).

Decline in fishing interest with increasing urbanization (Arlinghaus et al., 2015) was detected in this research as well. The county that covers the capital of Croatia - the City of Zagreb - expressed also a low angler participation of $0.17 \%$. So the remaining 13 inland counties were further analyzed. The percentage of recreational fishers varied between $0.56 \%$ in Krapina-Zagorje County and $3.73 \%$ in Međimurje County, with an average of $1.64 \pm 0.81 \%$ which can be compared to the value of $1.8 \%$ in South Africa, but is much below the average for Europe (mostly western and northern countries), which is about $11 \%$ (Arlinghaus et al., 2015). Four counties, although having the lowest GDP (lower than 6,500 euros per capita), do not show the relationship between GDP and percentage of anglers that is between 1.11 and 2.14\% (PožegaSlavonia, Slavonski Brod-Posavina, Virovitica-Podravina and Vukovar-Sirmium), indicating that angling tradition is the most important. The remaining nine counties, with GDP over 6,500 euros per capita show significant increase of angler participation with the increase of GDP (Fig. 3), which corresponds to the statement of Smith (1986) that interest in recreational fishing rises sharply with initial economic development of a given society.

The county of the City of Zagreb has the highest GDP per capita by far (19,105 euros) and highest population density $\left(1,247\right.$ inhabitants per $\left.\mathrm{km}^{2}\right)$. The other inland county with the highest values, Međimurje County, has GDP per capita of 9,284 euros and 154 inhabitants per $\mathrm{km}^{2}$. Therefore, low angler participation in the County of Zagreb $(0.17 \%)$ confirms the conclusions that recreational fishing first rises with economic development but then declines after reaching a peak in fishing participation (Sutton, 2007; Arlinghaus et al., 2015), assuming that all other inland counties are an example for the increase and Zagreb the sole example of decline because of its development in comparison to the rest of the country. The population density in other inland counties did not show significant correlation to the angler participation $\left(y=1.205+0,007 ; R^{2}=0,111 ; p=0.265\right)$.

Since Croatia joined the European Union in 2013, many inhabitants have moved for work to other more developed member states. Consequently, in all counties but two (Zagreb and Istria), population decline has been detected (Croatian Bureau of Statistics, 2018). In 7 counties it has not affected the number of anglers, in 2 a slight rise was detected, while in 2 (Sisak-Moslavina and Slavonski BrodPosavina) a rise of anglers was significant $(p<0.05)$ in spite of population decline.

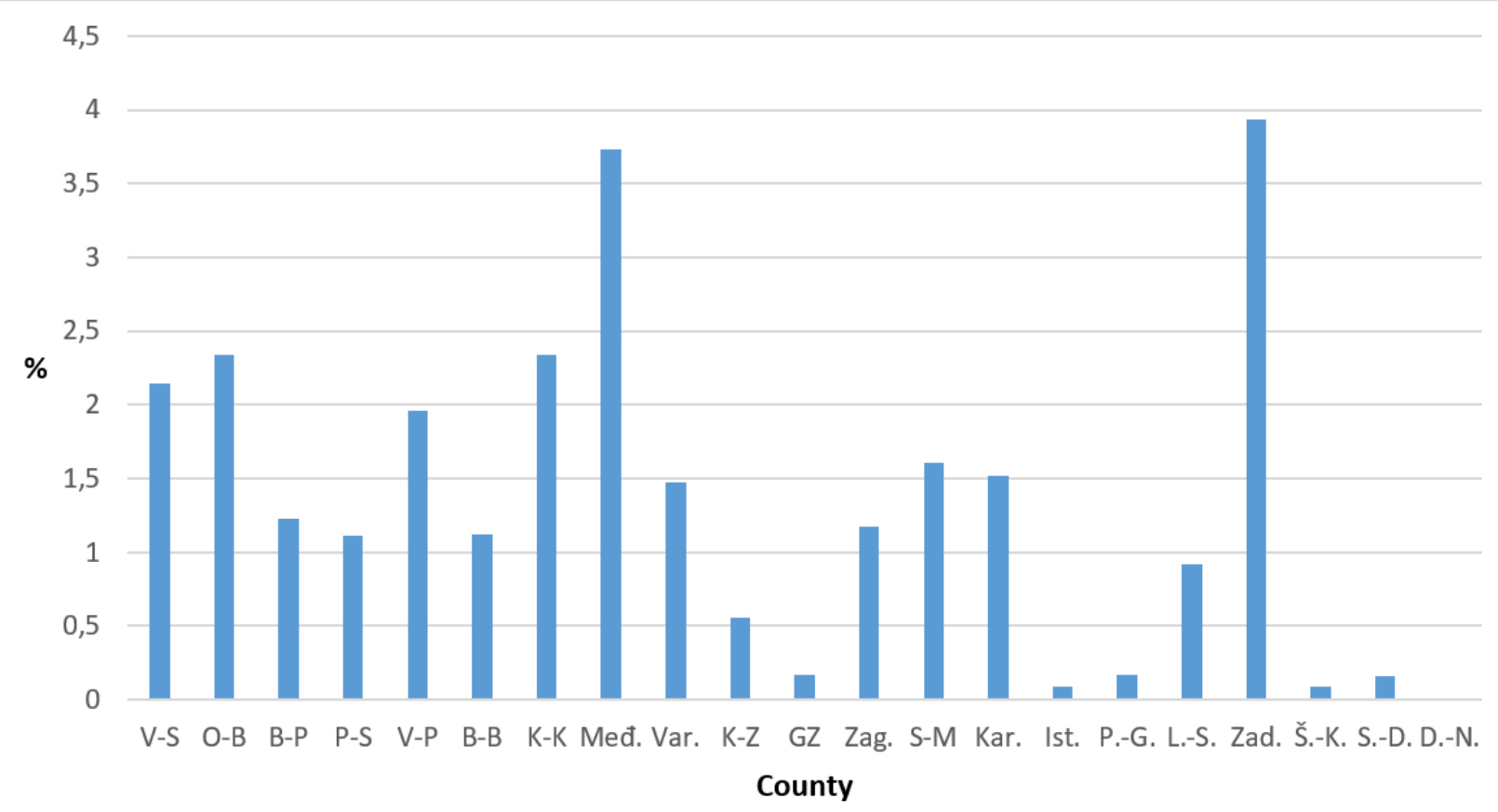

Fig 2. Percent of freshwater anglers (\%) across the counties of Croatia in 2015 (V-S= Vukovar-Sirmium, O-B= Osijek-Baranja, $B-P=$ Slavonski Brod-Posavina, V-P= Virovitica-Podravina, B-B= Bjelovar-Bilogora, K-K=Koprivnica-Križevci, Međ= Međimurje, Var= Varaždin, K-Z= Krapina-Zagorje, GZ= City of Zagreb, Zag= Zagreb, S-M= Sisak-Moslavina, Kar.= Karlovac, Ist= Istria, P-G= PrimorjeGorski Kotar, L-S= Lika-Senj, Zad= Zadar, Š-K= Šibenik-Knin, S-D= Split-Dalmatia, D-N= Dubrovnik-Neretva) 
On the other hand, a slight decrease of the number of anglers is evident in 2 counties, but is significant $(p<0.05)$ in the Vukovar-Sirmium county that suffered most the impact of war in Croatia (Fig. 4).

It can be concluded that in freshwater recreational fisheries in Croatia, the tradition (Salmi et al., 2006) and availability of fishing grounds (Adams et al. 1993) dominate the participation rates of anglers. However, there are indications of the influence of GDP per capita values. Densely populated County of Zagreb confirms that urbanization and much higher GDP per capita result in a much lower percentage of anglers, as stated by Aprahamian et al. (2010) and Arlinghaus (2015).

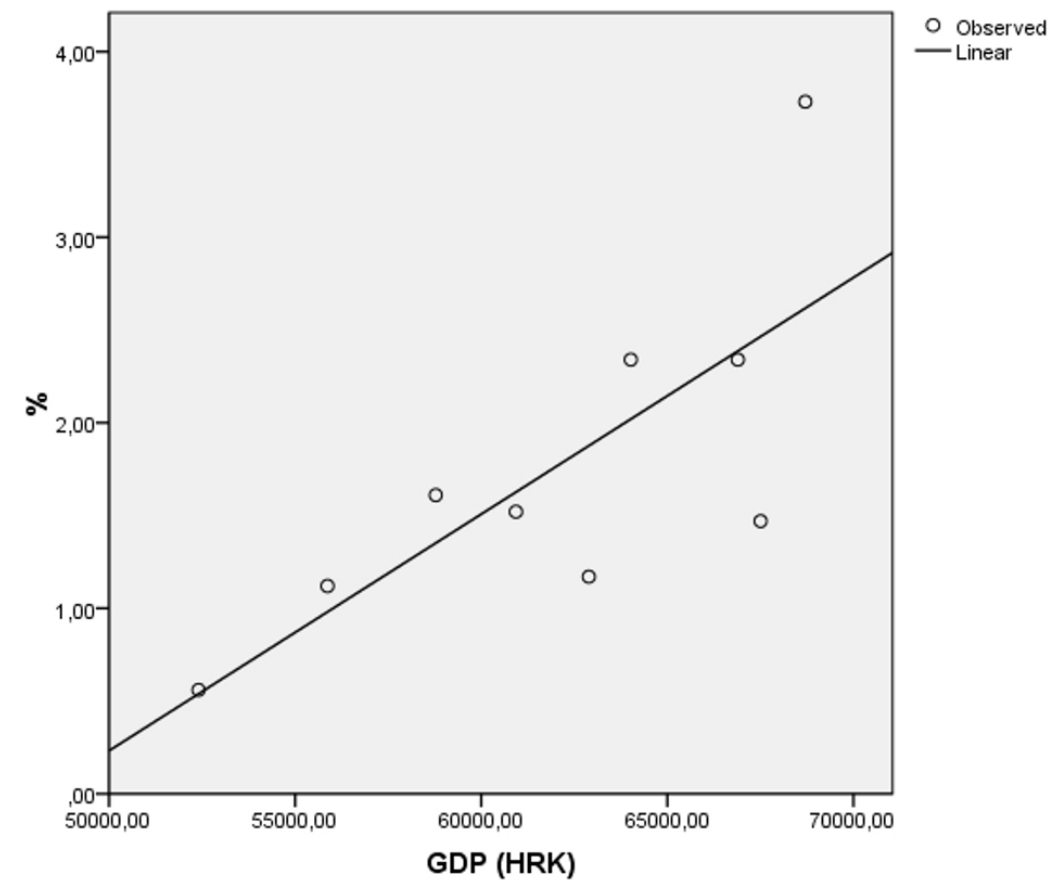

Fig 3. Correlation between the value of GDP per capita $(\mathrm{x})$ and \% of anglers $(\mathrm{y})$ across the nine inland counties with GDP per capita over 50,000 HRK (6.500 €), excluding the City of Zagreb in $2015\left(R^{2}=0.577 ; p<0.05\right)$

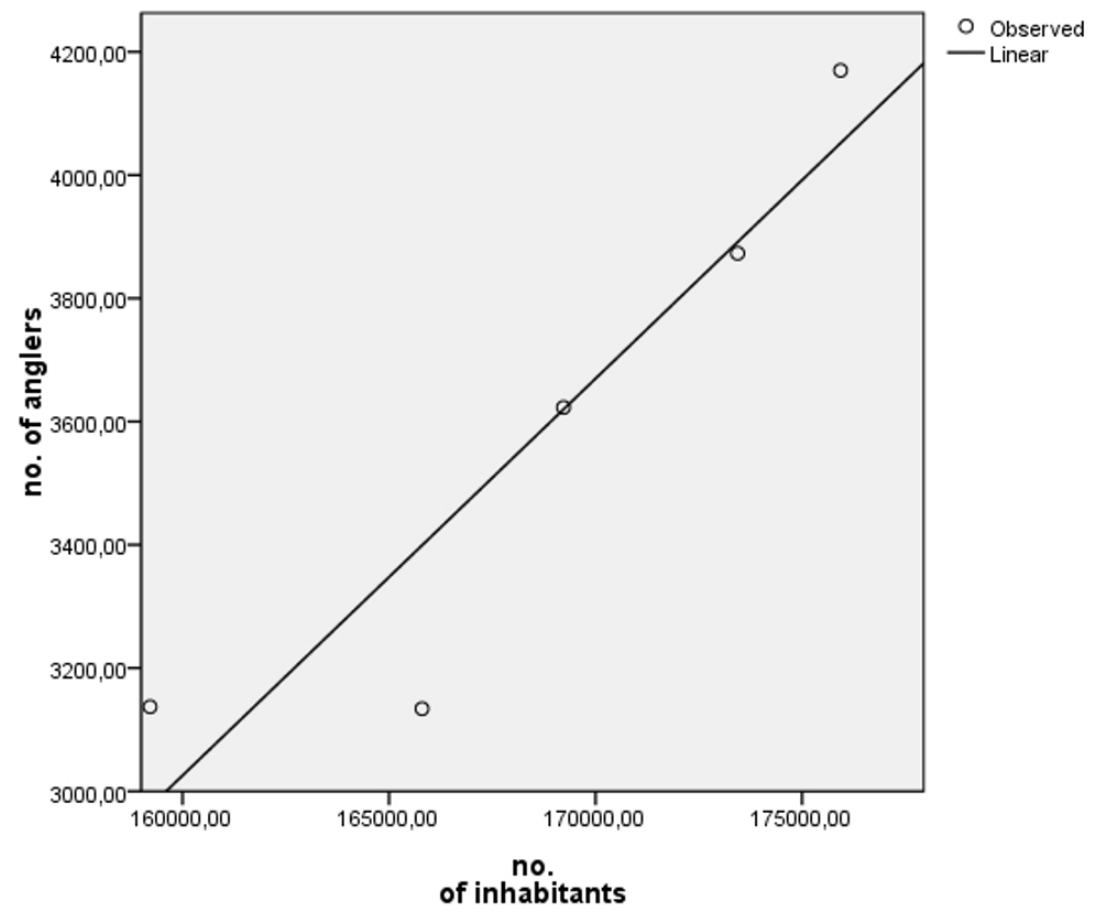

Fig 4. Correlation between the number of inhabitants $(x)$ and number of anglers $(y)$ in Vukovar-Sirmium County $\left(R^{2}=0.867 ; p<\right.$ $0.05)$ 


\section{SAŽETAK}

\section{UDIO SLATKOVODNIH REKREATIVNIH RIBOLO- VACA U HRVATSKIM ŽUPANIJAMA}

Cilj ovoga rada je utvrditi udio slatkovodnih ribolovaca u općoj populaciji u Hrvatskoj, njegovu promjenu kroz godine, kao i u pojedinim županijama. Unatoč stalnom gubitku stanovništva otkako je Hrvatska ušla u EU broj ribiča je lagano rastao, a udio u stanovništvu se kretao oko $1 \%$. Županije se mogu podijeliti u tri skupine - jadranske u kojima je dominantan morski ribolov, vrlo urbanizirani grad Zagreb, te preostale kontinentalne županije. Tradicija i dostupnost ribičkih voda dominiraju u udjelu ribiča. No, postoje indikacije utjecaja vrijednosti BDP-a, tako da županije koje imaju BDP veći od 6.500 eura per capita pokazuju značajnu pozitivnu korelaciju prema udjelu ribiča u njima $(p<0.05)$. Nasuprot tome, Grad Zagreb potvrđuje da visoka razina urbanizacije i znatno veći BDP rezultiraju u bitno manjem postotku rekreativnih ribolovaca.

\section{REFERENCES}

Aas, $\varnothing$. (2015): Programme and abstracts of the EIFAAC International Symposium - Recreational fishing in an era of change. Lillehammer, Norway $14-17$ June 2015, https://www.bior.lv/sites/default/files /publikacijas/262_EIFAAC_Symposium_2015_ Programme_and_abstracts_1.pdf (accessed on June $7^{\text {th }}$ 2019).

Adams, C.E., Thomas, J.K., Knowles, W.R. Jr. (1993): Explaining differences in angling rates in the United States. Fisheries 18, 11-17.

Aprahamian, M.W., Hickley, P., Shields, B.A., Mawle, G.W. (2010): Examining changes in participation in recreational fisheries in England and Wales. Fisheries Management and Ecology 17, 93-105.

Arlinghaus, R., Bork, M., Fladung, E. (2008): Understanding the heterogeneity of recreational anglers across an urban-rural gradient in a metropolitan area (Berlin, Germany), with implications for fisheries management. Fisheries Research, 92, 53-62.

Arlinghaus, R., Tillner, R., Bork, M. (2015): Explaining participation rates in recreational fishing across industrialised countries. Fisheries Management and Ecology, 22, 45-55.

Burkett, E. M., Winkler, R. L. (2019): Recreational fishing participation trends in Upper Great Lakes States: an age-period-cohort analysis. Human Dimensions of Wildlife, 24, 95-97.

Central Bureau of Statistics (2018): Press release. 55: 7.1.3., https://www.dzs.hr/Hrv_Eng/publication/2018/0701-03_01_2018.htm (accessed on January 24 ${ }^{\text {th }} 2019$ ).

Cowx, I. G. (2015): Characterisation of inland fisheries in Europe. Fisheries Management and Ecology, 22, 78-87.
Croatian Chamber of Economy (2018): BDP according to Counties, https://www.hgk.hr/documents/bdp-pozupanijama-u-2015-godini-final25ad8955342dfa.pdf (accessed on January 23 $3^{\text {rd } 2019)}$

Croatian Sport Fishing Association (2013): Croatian Sport Fishing Association (HŠRS) List of annual catches in sport fishing 2013.

Croatian Sport Fishing Association (2014): Croatian Sport Fishing Association (HŠRS) List of annual catches in sport fishing 2014.

Croatian Sport Fishing Association (2015): Croatian Sport Fishing Association (HŠRS) List of annual catches in sport fishing 2015.

Croatian Sport Fishing Association (2016): Croatian Sport Fishing Association (HŠRS) List of annual catches in sport fishing 2016.

Croatian Sport Fishing Association (2017): Croatian Sport Fishing Association (HŠRS) List of annual catches in sport fishing 2017.

da Silva, E. T., Ferreira, A. L., Furlaneto, M. (eds.) (2014): Program book of the $7^{\text {th }}$ World Recreational Fishing Conference on Change, transformation and adaptation in recreational fishing; 1-4 September 2014, Campinas. https://www.cpap.embrapa.br/pesca/online/ PESCA2014_PB_7WRFC.pdf (accessed on June $7^{\text {th }}$ 2019).

Dempson, J. B., Robertson, M. J., Cochrane, N. M., O'Connell, M. F., Porter, G. (2012): Changes in angler participation and demographics: analysis of a 17year licence stub return system for Atlantic salmon. Fisheries Management and Ecology 19, 333-343.

Driver, B. L., Knopf, R. C. (1976): Temporary escape: one product of sport fisheries management. Fisheries 1, 2-29.

Freire, K. M. F., Tubino, R. A., Monteiro-Neto, C., AndradeTubino, M. F., Belruss, C. G., Tomas, A. R. G., Tutui, S. L. S., Castro, P. M. G., Maruyama, L. S., Catella, A. C. (2016): Brazilian recreational fisheries: current status, challenges and future direction. Fisheries Management and Ecology, 23, 276-290.

Gray, P. A., Duwors, E., Villeneuve, M., Boyd, S., Legg, D. (2003): The socioeconomic significance of nature-based recreational in Canada. Environmental Monitoring and Assessment 86, 129-147.

Griffiths, S. P., Bryant, J., Raymond, H. F., Newcombe, P. A. (2017): Quantifying subjective human dimensions of recreational fishing: does good health come to those who bait? Fish and Fisheries, 18, 171-184.

Matulić, D., Šprem, N., Piria, M., Tomljanović, T., Treer, T., Safner, R., Aničić, I. (2010): Analysis of Recreational Fisheries in the Croatian Areas of the Sava and Danube Rivers. Agriculturae Conspectus Scientificus, 75, 183190.

Salmi, P., Toivonen, A. L., Mikkola, J. (2006): Impact of summer cottage residence on recreational fishing participation in Finland. Fisheries Management and Ecology, 13, 275-283. 
Smith, C. L. (1986): The life cycle of fisheries. Fisheries, $11,20-25$.

Sutton, S. G. (2007): Constraints on recreational fishing participation in Queensland, Australia. Fisheries, 32, 73-83.

Sutton, S., Dew, K., Higgs, J. (2009): Why Do People Drop Out of Recreational Fishing? A Study of Lapsed Fishers from Queensland, Australia. Fisheries, 34, 443-452.
World Bank (2019): GDP per capita (current US\$). World Bank national accounts data, and OECD National Accounts data files.. https://data.worldbank.org/ indicator/NY.GDP.PCAP.CD?locations=BR (accessed on 26 July 2019). 